\title{
Reply to Eaton and Pickavance
}

Brian Weatherson

Daniel Eaton and Timothy Pickavance note an interesting consequence of some popular versions of interest-relative invariantism (IRI). They take this consequence to be a reductio of (those versions of) IRI. I'll agree it is an interesting consequence, but argue that it cannot be a reductio. They take as a fixed point the following principle:

We take it to be rather obvious that one ought not be able to go from not knowing that $p$ to knowing that $p$ by getting evidence against $p$, nor should one be able to go from knowing that $p$ to not knowing that $p$ by getting evidence for $p$. (Eaton and Pickavance, 2015, 3142, emphasis in original)

The interesting consequence they note is that some versions of IRI violate this principle. It is possible, they argue, to come to know $p$ solely by getting evidence against it, at least on common versions of IRI.

But this is not a distinctive, or problematic, feature of IRI. It is true of any theory of knowledge that allows for Gettier cases. ${ }^{1}$ Assume that our protagonist $S$ has evidence that makes $q$ incredibly likely, and on that basis the agent believes $q$. Assume further that $q$ entails $p$, that $q$ is false, and $p$ is true. At least in typical such cases, $S$ will not know that $p .^{2}$ Now imagine that $S$ gets new evidence that makes $q$ very unlikely, but makes $r$, which also entails $p$, likely enough. If $r$ is true, then getting this new evidence could both decrease the evidential probability of $p$, and make it the case that $S$ knows that $p$. The converse is possible too. If the agent originally believes $p$ on the basis of true $r$, then gets evidence that undermines $r$, but makes $p$ more likely by making $q$, which is false and entails $p$, very likely, they will get evidence for $p$, and in virtue of that lose knowledge that $p$.

This point, that in Dharmottara/Gettier cases evidence can both create knowledge and be evidence against the proposition now known, is not novel. Brian (Weatherson, 2014) discusses some such cases, attributing them to Martin Smith. Weatherson argues that any theory that allows for defeaters will have this consequence, since it will always be possible for evidence to defeat a defeater, while ever

\footnotetext{
${ }^{1}$ Gettier cases should perhaps be called Dharmottara cases, since Dharmottara's 8th Century examples somewhat predate Gettier's, and are in some ways a little cleaner. Jennifer Nagel $(2014,57)$ has more discussion of Dharmottara.

${ }^{2}$ Is this restriction to 'typical' cases necessary? Perhaps - see recent work by Federico Luzzi (2010) for a good discussion of the point.
} 
so slightly lowering the evidential probability of $p$. The same will be true of any theory that puts a safety condition on knowledge, since it will always be possible that a new experience will make an agent's belief safer, while ever so slightly lowering its evidential probability.

Here's the particular way I think IRI should be implemented so that it has the consequence Eaton and Pickavance reveal. But note that the broader response I'm making to Eaton and Pickavance doesn't turn on any of the details here; it turns on interests being relevant to something that grounds the difference between knowledge and justified true belief.

I think interests matter to knowledge because they determine whether or not practical considerations generate defeaters. Someone who believes $p$, but has different preferences over live issues conditional on $p$ to what they have unconditionally, is in a way incoherent. This incoherence defeats any claim to knowledge of $p$. This kind of defeater should be interest-relative, for if it were not, we'd say that only things one is completely certain of can be known. If $p$ is not certain, one prefers $\$ 1$ to a bet that pays $\$ 1$ iff $p$. But conditional on $p$, one is indifferent between these bets. The interest-relativity becomes relevant here; this change in preference conditional on $p$ doesn't matter because one isn't really faced with such a choice.

If interest-relativity matters to knowledge because it matters to defeaters, or to safety, or to whatever explains Dharmottara/Gettier cases, then we should expect IRI to have just the consequence Eaton and Pickavance uncover. In short, any IRI theorist who thinks interests are relevant to knowledge in ways that go beyond how they are relevant to justified belief should view Eaton and Pickavance's results as an interesting discovery, not any kind of reductio.

\section{References}

Eaton, Daniel and Pickavance, Timothy. 2015. "Evidence against pragmatic encroachment.” Philosophical Studies 172:3135-3143, doi:10.1007/s11098-0150461-x.

Luzzi, Federico. 2010. “Counter-Closure.” Australasian Journal of Philosophy 88:673-683, doi:10.1080/00048400903341770.

Nagel, Jennifer. 2014. Knowledge: A Very Short Introduction. Oxford: Oxford University Press.

Weatherson, Brian. 2014. "Probability and Scepticism." In Dylan Dodd and Elia Zardini (eds.), Scepticism and Perceptual Justification, 71-86. Oxford: Oxford University Press. 